DOI: 10.46340/eppd.2021.8.5.7

Tetiana Khlivniuk

ORCID ID: https://orcid.org/0000-0002-7636-9088

Odesa I. I. Mechnikov National University, Ukraine

\title{
DIFFERENCES IN RESPONSE \\ TO THE SOCIAL EFFECTS OF THE COVID-19 \\ PANDEMIC: COMPARING CLASSIC WELFARE STATE MODELS
}

\author{
Тетяна Хлівнюк \\ Одеський національний університет імені І. І. Мечникова, Україна

\section{ВІДМІННОСТІ У РЕАГУВАННІ ПОРІВНЯННЯ КЛАСИЧНИХ МОДЕЛЕЙ СОЦАЛЬНОЇ ДЕРЖАВИ} \\ НА СОЦІАЛЬНІ НАСЛІДКИ ПАНДЕМІЇ COVID-19:
}

The absence of scientific consensus on understanding how the crisis caused by the spread of coronavirus will affect the state welfare institution has been noted: it will either strengthen it, significantly alter it, deepen stagnation or eliminate it, etc. Initiatives to prevent and counteract the consequences of the COVID-19 pandemic are analyzed using the example of classical welfare state models (social-democratic (Scandinavian, Nordic); corporatist (conservative); liberal). The first case is studied on the examples of Denmark, Norway, Finland, Sweden; the second one Germany, the third one - the USA. It is proved that changes in the architecture of the welfare state concerning the introduction of Scandinavian and corporatist models of tools to prevent a sharp increase in unemployment due to quarantine restrictions, simplify access to social benefits, pay attention to social protection of self-employed people, freelancers. It has been proven that changes in the architecture of state welfare concerned the introduction, first of all, in the states of the Scandinavian and corporatist models of tools to prevent a sharp increase in unemployment due to the quarantine, simplify access to social benefits, and pay attention to the problems of social protection of self-employed persons and freelancers. The strengthening of the focus of welfare states (especially the Scandinavian model) on state intervention in the economy as part of ensuring the accessibility of workplaces and living standards in line with modern standards was noted. Ethnic inequality and chauvinism to access social security have been shown to be acute in most countries during the pandemic. Limited coverage and existing social inequalities regarding access to social guarantees are clearly manifested even in countries with a liberal model of state welfare. National differences in the policy of developed welfare states in response to the social consequences of the coronavirus pandemic have been identified. The states of the Scandinavian and corporatist models long before the COVID-19 pandemic built strong social protection networks, pursued effective employment protection policies, etc.; therefore, during the pandemic, citizens received significant support. Instead, in the welfare states of the liberal model during the pandemic, the problem of having a quality social protection network has intensified, and inequality in terms of gender, race, and others has sharply increased.

Keywords: institute of welfare state, models of welfare state, COVID-19 pandemic, social protection, social policy, welfare systems.

Три класичні моделі соціальної держави (1. соціал-демократична (скандинавська, нордична); 2. корпоративістська (консервативна); 3. ліберальна) ${ }^{1}$, мають дуже відмінні режими соціального

\footnotetext{
${ }^{1}$ Esping-Andersen, G. (1990). The Three Worlds of Welfare Capitalism. Princeton: Princeton University Press.
} 
забезпечення ${ }^{1}$. Найчіткіше першу модель увиразнюють держави Північної Європи, другуНімеччина, третю- США. Попри схожість руйнівного впливу Covid-19 на ці високорозвинені держави, реагування на соціальні проблеми, породжені пандемією, відрізнялося своїми характеристиками. Власне уже давно сформовані моделі соціальної держави нині перебувають в доволі хиткому статусі. Не зрозуміло, як криза, зумовлена нинішньою пандемією, вплине на інститут соціальної держави: зміцнить, істотно видозмінить, поглибить стагнацію або й узагалі зумовить занепад. Для того, щоб наблизитися до відповіді на це питання, ми розглянемо реакції усіх трьох моделей соціальної держави на соціальні проблеми, породжені таким сильним соціальним подразником, яким виявилася пандемія Covid-19.

Інститути соціальної держави країн Північної Європи здавна відомі своїм універсалістським, всеохопним підходом до соціальної сфери. Вони мають стійку традицію активної політики ринку праці як інструмент реагування на економічні кризи, контролю за рівнем безробіття, уможливлення реального (а не декларативного) рівноправ'я. Саме успішна соціальна політика держав Північної Європи сприяла тому, що громадяни цих держав мають не лише найвищий рівень достатку, а і $€$ серед найщасливіших у світі ${ }^{2}$. Ті інструменти, які застосовували країни зі скандинавською моделлю соціальної держави, цікаві для вивчення в контексті оцінки перспектив тієї чи іншої моделі в умовах сильних соціальних потрясінь.

У політичній науці за останні три десятиліття (від часу появи концепції Г. Еспінг-Андерсена ${ }^{3}$ ) соціальні держави соціал-демократичного типу показали себе як комплексні, зі щедрими соціальними трансфертами та якісними соціальними послугами, особливо в частині охорони здоров'я, сімейної політики, догляду за дітьми та особами похилого віку ${ }^{4}$. Довгочасне ефективне функціонування цієї моделі уможливило високий рівень економічної, гендерної та ін. рівності, високий рівень залученості громадян на ринку праці, можливість швидкого повернення на ринок праці у випадку безробіття тощо ${ }^{5}$, хоч певні кризові моменти проглядаються в останні десятиліття ${ }^{6}$. Потрібно врахувати, що у порівняні з країнами, які впроваджують інші моделі соціальної держави, нордичні держави все ж мали вигідне макроекономічне становище, щоб ефективніше взяти під контроль соціальні наслідки пандемії.

Данія, Фінляндія, Норвегія та Швеція в рамках скандинавської моделі соціальної держави демонструють як спільні, так і відмінні підходи щодо реагування на пандемічні виклики. Соціальні умови в цих країнах доволі схожі. Така подібність - важлива передумова для з'ясування наявних відмінностей у соціальній політиці як відповідь на пандемію. Зупинимось на кількох кейсах в межах нордичних держав.

\footnotetext{
${ }^{1}$ Bariola, N., Collins, C. (2021). The Gendered Politics of Pandemic Relief: Labor and Family Policies in Denmark, Germany, and the United States During COVID-19. American Behavioral Scientist <https://journals.sagepub.com/doi/10.1177/00027642211003140> (2021, 29 July).

${ }^{2}$ Helliwell, J., Layard, R., Sachs, J., De Neve, J. E. (2020). World Happiness Report 2020. New York: Sustainable Development Solutions Network; Martela, F., Greve, B., Rothstein, B., Saari, J. (2020). The Nordic exceptionalism: What explains why the Nordic countries are constantly among the happiest in the world. In J. E. D. Neve, J. Helliwell, R. Layard, J. D. Sachs (Eds.), World Happiness Report, 2020. New York: Sustainable Development Solutions Network; Radcliff, B. (2013). The political economy of human happiness: How voters' choices determine the quality of life. Cambridge: Cambridge University Press.

${ }^{3}$ Esping-Andersen, G. (1990). The three worlds of welfare capitalism. Cambridge, MA: Polity Press.

${ }^{4}$ Arts, W., Gelissen, J. (2002). Three worlds of welfare capitalism or more? A state-of-the-art report. Journal of European Social Policy, 12 (2), 137-158; Blum, S., Kuhlmann, J., Schubert, K. (2020). The Routledge handbook of European welfare systems. Oxon: Routledge; Greve, B. (2016). Denmark: Still a Nordic welfare state after the changes of recent years? In K. Schubert, P. Villota, J. Kuhlman (eds.), Challenges to European welfare systems (pp. 159-176). Cham: Springer International Publishing; Kangas, O., Kvist, J. (2019). Nordic Welfare States. In B. Greve (Ed.), Routledge Handbook of the Welfare State. Oxon: Routledge, 124-136; Хома, Н. M. (2010). Особливості функціонування скандинавської моделі соціальної держави: порівняльний аспект.

Порівняльно-правові дослідження, 2, 157-165.

${ }^{5}$ Greve, B., Blomquist, P., Hvinden, B., van Gerven, M. (2021). Nordic welfare states - still standing or changed by the COVID-19 crisis? Social Policy \& Administration, 55 (2), 296.

${ }^{6}$ Хома, Н. М. (2010). Криза скандинавської моделі соціальної держави: причина, наслідки, шляхи виходу. Держава і право, 50, 700-708; Хома, Н. М. (2012). Моделі соиіальної держави: світовий та украӥнський досвід. Київ: Юридична думка; Khoma, N., Vdovychyn, I. (2020). Deconstruction of the Welfare State: The Impact of Globalization and Technological Factors. Revija za socijalnu politiku, 27 (3), 269-285.
} 
У Данії потужні загальнодержавні програми гарантування заробітної плати доповнили й до цього дієву мережу соціального захисту. Маємо враховувати, що данці платять одні з найвищих податків у світі, з яких фінансується зокрема й соціальна сфера. Ця держава однією з перших ввела локдаун та реорганізувала охорону здоров'я, однак однією з перших відновила роботу шкіл та дошкільних закладів. Було враховано, що зайнятість батьків узалежнена від функціонування системи догляду за дітьми, особливо для працівниць-матерів. Ще до пандемії Covid-19 уряд Данії розробив та реалізовував активну модель політики на ринку праці - «гнучка безпека» (flexicurity), яка поєднує гнучкість ринку праці в умовах динамічної економіки та безпеку працівників. Така модель власне призначена для обмеження фінансових ризиків і роботодавців, і працівників ${ }^{1}$. Завдяки їй вдалося уникнути масового спаду та високого рівня безробіття.

У відповідь на пандемію данський уряд реалізував один з наймасштабніших економічних планів у світі²: держава покривала до 90\% заробітної плати працівникам недержавного сектора, які пішли на самоізоляцію; приватному бізнесу уряд виплатив компенсації, щоб не відбулося вивільнення працівників; фрилансери та самозайняті працівники мали право на отримання до 75\% очікуваного доходу, втраченого через локдауни; працівників державного сектора перевели на віддалену роботу без втрат у зарплаті; уряд взяв на себе компенсації витрат за орендну плату, покривав відсотки по кредитах з метою недопущення банкрутства суб'єктів господарювання тощо. Саме уряд (а не роботодавці) взяв на себе виплати за листками непрацездатності від першого дня інфікування Covid-19. Ціна таких урядових ініціатив була дуже високою, однак данський уряд врахував, що стрімке зростання безробіття в умовах локдаунів, різке зниження сукупного попиту вартуватимуть надалі набагато більше, а стрімке зростання безробіття зумовить низку нових соціальних проблем.

Отже, в Данії основними новими інструментами соціального захисту, створеними під час коронавірусної кризи, були: підтримка компаній в частині збереження кадрового потенціалу; підтримка самозайнятих працівників, фрилансерів, осіб, які працюють в межах платформної економіки та ін. Ці заходи були спрямовані на зменшення соціального ризику зростання безробіття та недопущення різкого зниження доходів працездатного населення. Водночас наразі нема ознак постійних змін в ту чи іншу сторону в частині щедрості й універсальності данської соціальної держави. Тиск наслідків пандемії на державні фінанси, ріст безробіття може тривати довгочасно, тим паче, що пандемія Covid-19 має хвилеподібний перебіг і наразі прогнози щодо ії зупинення не $\epsilon$ оптимістичними.

В Фінляндії державні ініціативи у сфері соціального забезпечення в умовах кризи Covid-19 також зосередилися на пом'якшенні економічних труднощів через локдауни, захисті ринку праці від початкових потрясінь. Найперше, було підтримано найуразливіші сектори малого та середнього бізнесу, захищено від банкрутства суб'єктів господарювання, не допущено масове вивільнення кадрів ${ }^{3}$. Згодом великі пакети підтримки були призначені потужним державним компаніям (авіакомпанія «Finnair» та ін.), окремим секторам (обслуговування, культури, охорони здоров'я, туризму та ін.).

Однією з відмінностей Фінляндії від інших нордичних держав була у порівнянні менша залученість профспілок у процес переговорів, але пояснення цьому можна знайти в тому, що ще до пандемії Covid-19 були належно унормовані питання соціального захисту за надзвичайних ситуацій. Зокрема, існувала схема захисту на випадок тимчасових звільнень працівників. Однак від березня 2021 року порядок надання виплат вимушено вивільненим працівникам був удосконалений, щоб максимально компенсувати компаніям та вивільненим працівникам втрати. Уряд С. Марін ініціював механізми вдосконалення захисту у випадку безробіття для фрилансерів, полегшивши їм доступ до соціальної допомоги. Загалом комплекс заходів соціальної підтримки з боку держави під час пандемії у Фінляндії $є$ широким і багатовекторним.

\footnotetext{
${ }^{1}$ Wiking, M. (2016). Why Danes happily pay high rates of taxes. US News and World Report <https://www.usnews.com/news/best-countries/articles/2016-01-20/why-danes-happily-pay-high-rates-of-taxes> (2021, July, 29).

2 Thompson, D. (2020). Do more - fast. Don't wait. The Atlantic, March 24.

${ }^{3}$ Keskimäki, I., Atkins, S., Merisalo, M., Rautianen, P., Tynkkynen, L.-K. (2020). Policy responses for Finland. Measures in other sectors. COVID-19 Health System Response Monitor <https://www.covid19healthsystem.org/ countries/finland/ livinghit.aspx?Section=6.1\%20Measures\%20in\%20other\%20s > (2021, July, 24).
} 
Загалом у державах з нордичною моделлю соціальної держави велика кількість урядових «антикоронавірусних» соціальних ініціатив мала тимчасовий характер, як-от підтримка бізнесу, зміна правил отримання допомоги у зв'язку з безробіттям тощо. Надалі, припускаємо, найбільші зміни стосуватимуться охорони здоров'я, на яку витрати тільки зростатимуть. Тим більше, що серед виборців у державах Північної Свропи значною є підтримка саме сфери охорони здоров'я ${ }^{1}$. Наразі найбільші зміни у архітектурі соціальної держави на Півночі Європи стосувалися впровадження інструментів запобігання різкому росту безробіття через карантинні обмеження, спрощення доступу до різних соціальних виплат, звернення уваги (вперше) на проблеми захисту самозайнятих, фрилансерів.

Наразі не зрозуміло, чи після завершення коронакризи такі новації зберігатимуться. Наприклад, хоч уряд фінської прем'єр-міністра С. Марін станом на середину 2021 року ще не оголошував якихось жорстких заходів щодо інституту соціальної держави (в напрямку економії), але вже наявний високий державний дефіцит актуалізує питання можливого згортання соціальних виплат, зменшення щедрості соціальної держави після завершення пандемії. Також у Норвегії серйозні загрози для стійкості інституту соціальної держави можуть бути зумовлені довготривалим негативним впливом Covid-19 на міжнародний попит та конкурентоспроможність норвезького бізнесу. Глобальне економічне уповільнення також очікувано перешкодить перспективам працевлаштування молоді, яка вийде на ринок праці найближчими роками.

Хоч скандинавська (соціал-демократична) модель соціальної держави показала чи не найвищу результативність у протидії соціальним наслідкам пандемії коронавірусу, однак $\epsilon$ проблеми, які загрожують іiі стійкості у перспективі. Мова про прояви етнічної нерівності та шовінізму добробуту ${ }^{2}$. Наприклад, у районах Осло, де проживає найбільше громадян 3 найнижчими доходами та представників етнічних меншин, рівень уражених Covid-19 $\epsilon$ найвищим ${ }^{3}$. Схожа до норвезької ситуація й у Швеції ${ }^{4}$, Данії ${ }^{5}$, Фінляндії ${ }^{6}$, не кажучи вже про менш розвинені в соціальному плані держави.

Загалом за час пандемії інститут соціальної держави у скандинавських державах розширив охоплення нових категорій працівників, цим сам посилюючи свій вплив на суспільство. Це особливо видно в спробах покрити ризики самозайнятих людей, фрилансерів, осіб, які працюють в межах платформної економіки, позаяк довго ці категорії працездатного населення розглядали поза сферою соціального забезпечення ${ }^{7}$. Відтак для таких категорій населення коронавірусна криза навіть мала деякий позитив, бо стала першим кроком для повнішого їх включення в систему соціального захисту.

Коронакриза не змінила основних характеристик та універсальності північних держав соціального забезпечення, але посилила фокус уваги на державному втручанні в економіку як частині забезпечення робочих місць та відповідного сучасним стандартам рівень життя громадян.

\footnotetext{
${ }^{1}$ Meuleman, B., van Oorschot, W., Gugushvili, D. et al. (2018). The Past, Present and Future of European Welfare Attitudes: Topline Results from Round 8 of the European Social Survey. ESS Topline Series; Roosma, F., Gelissen, J., Van Oorschot, W. (2013). The multidimensionality of welfare state attitudes: A European cross-national study.

Social Indicators Research, 113 (1), 235-255.

${ }^{2}$ Greve, B. (2019). Welfare, populism and welfare chauvinism. Bristol: Policy Press.

${ }^{3}$ Norwegian Government (2020). Economic measures in Norway in response to Covid-19

<https://www.regjeringen.no/en/topics/the-economy/economic-policy/economic-measures-in-norway-in-responseto-covid-19/id2703484/> (2021, 14 June); Norwegian Government (2020). Meld. St. 2 (2019-2020) Melding til Stortinget - Revidert nasjonalbudsjett <https://www.regjeringen.no/contentassets/f7f > (2021, June, 20).

${ }^{4}$ Public Health Agency (2020). Veckorapport om Covid-19, vecka $32<$ https://www.folkhalsomyndigheten.se/globalassets/ statistik-uppfoljning/smittsamma-sjukdomar/veckorapporter-covid-19/2020/covid-19-veckorapport-vecka-32-final-v2.pdf> (2021, June, 20).

${ }^{5}$ COVID-19 i Danmark. Epidemiologisk trend og fokus: Herkomst (etncitet) (2020). Statens Serun Institut <https://files.ssi.dk/COVID19-epi-trendogfokus-07052020-4eu7> (2021, June, 20).

${ }^{6}$ Hirvonen, S. (2020). Helsingissä somalinkielisten koronavirustartunnat ovat selkeästi lisääntyneet, kaupunki ja HUS huolestuneita tilanteesta - Apulaispormestari vetoaa ohjeiden noudattamiseen alkavan ramadanin aikana. Yle <https://yle.fi/uutiset/3-11305135> (2021, June, 20).

${ }^{7}$ Behrendt, C., Nguyen, Q. A., Rani, U. (2019). Social protection systems and the future of work: Ensuring social security for digital platform workers. International Social Security Review, 72 (3), 17-41; Hill, S. (2015). Raw deal. How the "Uber Economy" and runaway capitalism are schrewing American workers. New York: St. Martins Press.
} 
Станом на сьогодні бачимо, що останні зміни увиразнюють посилення інклюзивної соціальної політики ${ }^{1}$, яка спрямована підтримувати високий рівень рівності, характерний країнам Північної Свропи.

Якщо ж звернутися до кейса корпоративістської (консервативної) моделі соціальної держави ${ }^{2}$ на прикладі Німеччини, то тут відповіді на Covid-19 базуються на співпраці між державою та суспільством. Проведені реформи зробили ринок праці більш гнучким ${ }^{3}$, зокрема уряд А. Меркель надав гарантії великому бізнесу та гранти малому бізнесу, фінансову підтримку самозайнятим працівникам і фрилансерам.

Найпотужнішим заходом боротьби з рецесійними наслідками пандемії у Німеччині $\epsilon$ соціальна програма «Kurzarbeit» 3 виплати компенсацій працівникам, які вимушено перейшли на неповну зайнятість. Це інструмент антикризового управління, який захистив доходи німецьких працівників та підтримав докризовий рівень сукупного попиту. Роботодавці не звільнили працівників, а лише скоротили їх робочий час. Уряд виплатив працівникам $60 \%$ або $67 \%$ (за наявності дитини) їх середньої заробітної плати за ті години, які не були фактично відпрацьовані 3 причини локдауну. У перспективі (якщо того вимагатиме ситуація) відсотки можуть бути переглянуті (80\% та 87\% відповідно). Саме завдяки реалізації програми «Kurzarbeit» федеральний уряд зберіг у Німеччині 2,2 млн робочих місць і запобіг хвилі банкрутств у перші місяці пандемії.

Фактично німецька модель збереження неповної зайнятості дозволила зберегти в Німеччині у шість разів більше робочих місць, ніж за період фінансово-економічної кризи 2008-2009 років. У згаданий період тільки працівникам великих корпорацій, які були переведені на неповну зайнятість, вдалося зберегти робочі місця, уникнувши звільнення. Відтак, в умовах пандемії німецькому уряду вдалося успішно реалізувати програму державної допомоги бізнесу і цим зберегти важливі висококваліфіковані кадри. Мотивацію цього можна показати на прикладі середніх та малих високоспеціалізованих машинобудівних компаній: якщо вони втратять добре підготовлені кадри, то ризикують не відновити виробництво.

Зауважимо, що реалізація програми «Kurzarbeit» уможливилась завдяки багаторічній високій зайнятості німецьких працівників, а відтак - накопиченню резерву зі страхових внесків на випадок безробіття. Тобто, свого роду ощадливість (можна згадати про вплив протестантської етики), традиція фіскальної розсудливості підготували Німеччину в інституційному та фінансовому плані до протистояння спаду. Відзначимо, що окрім виплат від держави за програмою «Kurzarbeit», багато німецьких роботодавців додатково фінансово підтримували своїх працівників (корпоративна соціальна відповідальність).

Хоч за час пандемії в Німеччині справді було значно розширено наявні програми, надано щедрі субсидії, але деякі питання через домінування консервативних суспільних настроїв залишилися недостатньо пропрацьовані. Наприклад, попри офіційні державні зобов'язання зменшити гендерну нерівність, панівна культурна спадщина сімейної моделі «батько-годувальник і матір-вихователь», зумовила ситуацію, за якої, наприклад, відновлення роботи закладів шкільної та дошкільної освіти не стало першочерговим завданням держави. Це дуже ускладнило активність жінок-матерів на ринку праці в умовах пандемії Covid-19. Також федеральна програма «Kurzarbeit» не охопила працівників, які до пандемії залучалися на тимчасові, сезонні роботи й отримували порівняно низьку оплату. Разом із тим аж $28 \%$ жінок-працівниць Німеччини залучені саме до таких робіт ${ }^{4}$.

Якщо у Німеччині політична відповідь державних інститутів на пандемію була чіткою та ефективною, то у США, де реалізується ліберальна модель соціальної держави, реагування на пандемію не мало комплексного характеру, характеризувалося непослідовністю. Великі приватні бізнес-структури, особливо в стійких секторах економіки, у своїй більшості пропонували

\footnotetext{
${ }^{1}$ Greve, B., Blomquist, P., Hvinden, B., van Gerven, M. (2021). Nordic welfare states - still standing or changed by the COVID-19 crisis? Social Policy \& Administration, 55 (2), 307.

${ }^{2}$ Leitner, S., Lessenich, S. (2003). Assessing welfare state change: The German social insurance state between reciprocity and solidarity. Journal of Public Policy, 23(3), 325-347; Esping-Andersen, G. (1999). Social Foundations of Postindustrial Economies. Oxford: Oxford University Press.

${ }^{3}$ Scruggs, L. A., Allan, J. P. (2008). Social Stratification and Welfare Regimes for the Twenty-first Century: Revisiting the Three Worlds of Welfare Capitalism. World Politics, 60 (4), 642-664.

${ }^{4}$ Cook, R., Grimshaw, D. (2020). A gendered lens on COVID-19 employment and social policies in Europe. European Societies, 23 (1), 215-227.
} 
працівникам-батькам підтримку під час карантинних обмежень. Однак для багатьох американських родин з працюючими батьками локдаун призвів до довготривалої невизначеності, погіршення якості життя. Особливо катастрофічними були наслідки локдауну для жінок з уразливих соціальних груп. Уряд США надавав меншу підтримку своїм громадянам, аніж уряди країн зі скандинавською або корпоративною моделями соціальної держави. Якщо в цих державах було істотно розширено чинні програми та засоби захисту вже на початку пандемії, щоб допомогти працівникам справитися 3 наслідками локдаунів, то у США, як ліберальній соціальній державі, в умовах пандемії нерівність сильно поглибилась.

Можна припустити, що наслідки пандемії COVID-19 у CША були б менш згубними, якби влада краще координувала протидію проблемам, використовуючи інструменти соціальної держави. Втім американська система охорони здоров'я демонструвала великі проблеми ще до пандемії Covid19, а ця криза лише посилила ix $^{1}$. Відсутність універсальної медичної допомоги, виражена зорієнтованість ліберальної моделі соціальної держави на приватне страхування, яке фінансується роботодавцем, призвело до втрати мільйонами американців за час пандемії не лише робочого місця, а водночас й медичного страхування. У звіті Urban Institute за 2020 рік вказано: 10,1 млн громадян США втратили медичне страхування, яке гарантували їм раніше роботодавці ${ }^{2}$.

Попри згадані критичні моменти, владні інституції США прийняли низку програм підтримки громадян, бізнесу та корпорацій упродовж кількох перших місяців пандемії. Йдеться про розширення страхування на випадок безробіття, програму оплачуваних відпусток, допомогу малому бізнесу, фінансову допомогу великим корпораціям, щомісячні грошові виплати (1200 дол. на дорослого та 500 дол. на кожну дитину). Але те, як ці заходи реалізовувалися, засвідчило їх обмежене охоплення та наявні соціальні нерівності в доступі до соціальних гарантій. Лише у перші місяці пандемії було виділено бл. 800 млрд дол. на розширення допомоги по безробіттю американцям, які втратили роботу через пандемію. У середньому безробітним було компенсовано 45\% втраченого доходу, хоча в окремих штатах є приклади вищих виплат. Щонайпізніше до вересня 2021 року у більшості штатів виплати на підтримку безробітних припиняються (у кожному штаті визначень своя дата фінішу надання такої соціальної підтримки) й наразі не очевидно, чи будуть вони продовжені ${ }^{3}$. У тих штатах, де влітку 202 року виплати були припинені (Арканзас, Індіана, Меріленд, Флорида та ін.), вже фіксується звернення зі судовими позовами. В цих позовах основний акцент позивачів робився на неспроможності через дострокове скасування федеральних програм покрити основні витрати, включаючи орендну плату, комунальні платежі. Не зрозуміло наразі, якою буде позиція на державному та федеральному рівні з огляду на стрімку висхідну динаміку штаму «Дельта».

На відміну від програм підтримки тих, хто втратив роботу в результаті карантинних антиковідних обмежень, у країнах з скандинавською та корпоративістською моделями соціальної держави, у США роботодавці не зверталися безпосередньо до уряду, не озвучували вимог запобігти вивільненням. Натомість, американці після звільнення самі були вимішені подавати заявки на отримання пільг. Це спричинило значні соціальні наслідки безробіття: підвищений стрес, невизначеність, відсутність медичного обслуговування тощо ${ }^{4}$. До того ж на бюрократичну систему практично в один момент різко посилився тиск через зростання заявників. Відтак знизилась якісь, ефективність роботи управлінської системи, відбувалися збої на веб-сайтах, де реєструвалися звернення безробітних. Склалася ситуація, коли багато американців не змогли податися на отримання допомоги та отримати виплати. I навіть у випадку отримання тої чи іншої соціальної підтримки від держави, іiі обсяги для американців були значно меншими, аніж у згаданих вище Данії, Німеччині та інших державах.

Небагато у США скористалися програмами федеральних відпусток, що передусім зумовлено низькою інформованістю про таку програму. За результатами опитування видання «The New York

\footnotetext{
${ }^{1}$ Blumenthal, D., Fowler, E. J., Abrams, M., Collins, S. R. (2020). Covid-19: Implications for the Health Care System. New England Journal of Medicine, 383 (15), 1483-1488.

${ }^{2}$ Banthin, J., Simpson, M., Buettgens, M., Blumberg, L. J., Wang, R. (2020). Changes in health insurance coverage due to the COVID-19 recession: Preliminary estimates using microsimulation. Washington: Urban Institute.

${ }^{3}$ Gonzalez, O., Davis, L. M. (2021). What's happening to federal unemployment benefits after summer?

Here's what we know. CNET <https://www.cnet.com/personal-finance/your-money/whats-happening-to-federalunemployment-benefits-after-summer-heres-what-we-know/> (2021, June, 17).

${ }^{4}$ Rao, A. H. (2020). Crunch time: How married couples confront unemployment. Oakland: University of California Press.
} 
Times» до травня 2020 року близько половини громадян США нічого не знали, або були дуже поверхово інформовані про потенційні переваги такої програми; лише $13 \%$ опитаних підтвердили, що були належно проінформовані про неї ${ }^{1}$ При цьому варто рахувати соціальний зріз читацької аудиторії «The New York Times», з числа якої були респонденти цього опитування. До того ж широко поширювалась думка, що така політика оплачуваних відпусток (попри надзвичайність ситуації, зумовленої Covid-19), потенційно зашкодити бізнесу. Звіт Bipartisan Policy Center ${ }^{2}$ показав, що 37\% керівників малого бізнесу переконані, що навіть у пандемічні часи політика додаткової соціальної підтримки населення знизить стійкість їх бізнесу. Це уповні узгоджується зі змістом ліберальної моделі соціальної держави, яку впроваджують у США: акцент не на соціальну підтримку громадян, а на їх мотивацію до праці в будь-яких умовах задля зростання доходів, а відтак - зменшення підстав звертатися за різного типу виплатами до держави. «Приватизація соціальних проблем $є$ характерною культурною особливістю режиму ліберального добробуту США» ${ }^{3}$.

Ще однією структурною проблемою системи охорони здоров'я, яка посилилася внаслідок кризи Covid-19, є історична нездатність забезпечити адекватну та рівноправну допомогу афроамериканцям і латиноамериканцям. Ці групи населення не лише менше охоплені медичним страхуванням, а й частіше страждають на хронічні захворювання, які посилюють ризики летальності хворих на Covid-194. Люди з небілим кольором шкіри також частіше займаються нестабільною та шкідливою для здоров'я роботою, яка збільшує ризик їх інфікування коронавірусом ${ }^{5}$. Результатом цього $є$ те, що латиноамериканці та афроамериканці у 2,8 раза частіше помирають від Covid-19, ніж білошкірі громадяни США 6 . Загалом доступ до різних соціальних програм є сильно стратифікований соціально-економічним статусом ${ }^{7}$. Наприклад, хоч ослаблена в США система догляду за дітьми завдала шкоди всім сім'ям, наслідки особливо руйнівні є саме для небілих американців. Вони мають значно менший доступ до гнучких графіків та варіантів роботи вдома, ніж білошкірі американці. Жіноцтво з небілим кольором шкіри непропорційно представлені серед працівників з високим рівнем зараження на Covid-198. Одинокі матері, які покладалися на дитячі дошкільні заклади, розширені мережі для догляду за дітьми, в часи пандемії значною мірою виявилися відрізаними від цієї вирішальної підтримки9. Виникають загрози продовольчій безпеці родин. Сім'ї афро- та латиноамериканців удвічі частіше зіткнулися з загрозою продовольчій безпеці, аніж родини білошкірих американців ${ }^{10}$.

\footnotetext{
${ }^{1}$ Miller, C. C., Tankersley, J. (2020). Paid leave law tries to help millions in crisis: Many haven’t heard of it. The New York Times, May, 8.

${ }^{2}$ Schweer, A., Rodríguez, J. (2020). New BPC/morning consult survey of small business owners:

Family and child responsibilities are top challenges during COVID-19. Bipartisan Policy Center

$<$ https://bipartisanpolicy.org/blog/new-bpc-morning-consult-survey-of-small-business-owners-family-and-childresponsibilities-are-top-challenge-during-covid-19/> (2021, May, 18).

${ }^{3}$ Bariola, N., Collins, C. (2021). The Gendered Politics of Pandemic Relief: Labor and Family Policies in Denmark, Germany, and the United States During COVID-19. American Behavioral Scientist

<https://journals.sagepub.com/doi/10.1177/00027642211003140> (2021, May, 21).

${ }^{4}$ Blumenthal, D., Fowler, E. J., Abrams, M., Collins, S. R. (2020). Covid-19: Implications for the Health Care System. New England Journal of Medicine, 383 (15), 1483-1488.

${ }^{5}$ Dubay, L., Aarons, J., Brown, K. S., Kenney, G. M. (2020). How risk of exposure to the Coronavirus at work varies by race and ethnicity. Washington: Urban Institute.

${ }^{6}$ NCIRD (2020). COVID-19 hospitalization and death by race/ethnicity. Centers for Disease Control and Prevention $<$ https://www.cdc.gov/coronavirus/2019-ncov/covid-data/investigations-discovery/hospitalization-death-by-race-ethnicity.html> (2021, June, 11).

${ }^{7}$ Miller, C. C. (2020, September 17). Private tutors, pop-up schools or nothing at all: How employers are helping parents. The New York Times.

${ }^{8}$ Novoa, C. (2020). How child care disruptions hurt parents of color most. Center for American Progress <https://www.americanprogress.org/issues/early-childhood/news/2020/06/29/486977/child-care-disruptions-hurt-parents-color/> (2021, July, 02).

${ }^{9}$ Powell, C. (2020). The color and gender of COVID: Essential workers, not disposable people. Think Global Health <https://www.thinkglobalhealth.org/article/color-and-gender-covid-essential-workers-not-disposable-people> (2021, July, 23).

${ }^{10}$ Schanzenbach, D. W., Pitts, A. (2020). How much has food insecurity risen? Evidence from the Census Household Pulse Survey. Institute for Policy Research Rapid Research Report <https://www.ipr.northwestern.edu/documents/ reports/ipr-rapid-researchreports-pulse-hh-data-10-june-2020.pdf> (2021, August, 01).
} 
Висновки. Пандемія Covid-19 засвідчила, що інститут соціальної держави має більшу увагу приділити запобіганню різних форми дискримінації, нерівності в питаннях доступу до соціальної підтримки з боку державних інституцій, особливо в умовах надзвичайних ситуацій, частота яких зростає останнім часом. Ця пандемія особливо посилила тиск на інститут сім'ї в частині вимушеного поєднання роботи та догляду за членами сім'ї (дітьми, хворими), загострила проблему гендерних розривів, «оголила» наявні проблеми системи охорони здоров'я, підтримки безробітних тощо. Пандемічна криза виразно засвідчила уразливість особливо жінок в питаннях зайнятості ${ }^{1}$, проблему нерівності в доступі до систем соціального захисту окремих соціально уразливих груп населення (порушення принципу рівності, інтолерантність).

Аналіз показав національні розбіжності у політиці розвинених держав, де функціонує інститут соціальної держави, у реагуванні на соціальні наслідки пандемії коронавірусу. Руйнівний вплив пандеміï Covid-19 відчутно пом'якшувався в країнах зі скандинавською та консервативною (корпоративістською) моделями соціальної держави. Натомість у державах з ліберальною моделлю роль соціальної держави була значно меншою. Причину цього можна вбачати в тому, що держави зі скандинавською (соціал-демократичною) та консервативно-корпоративістською моделями соціальної держави задовго до пандемії Covid-19 вибудували міцні мережі соціального захисту, послідовну та ефективну політику захисту зайнятості, накопичили резерв зі страхових внесків на випадок безробіття та й загалом є більш щедрими, аніж соціальні держави ліберального типу. Відтак під час пандемії громадяни цих країн отримували кращу підтримку. Натомість у державах з ліберальною моделлю, яка традиційно перекладає питання соціального захисту з держави на роботодавця та працівника, за час пандемії коронавірусної інфекції сильно зросла нерівність в доступі до соціальних гарантій, а сам обсяг соціальної «антиковідної» підтримки є має системного характеру та не враховує можливі деструктивні наслідки нинішніх соціальних проблем для майбутнього.

\section{References:}

1. Arts, W., Gelissen, J. (2002). Three worlds of welfare capitalism or more? A state-of-the-art report. Journal of European Social Policy, 12 (2), 137-158. [in English].

2. Banthin, J., Simpson, M., Buettgens, M., Blumberg, L. J., Wang, R. (2020). Changes in health insurance coverage due to the COVID-19 recession: Preliminary estimates using microsimulation. Washington: Urban Institute. [in English].

3. Bariola, N., Collins, C. (2021). The Gendered Politics of Pandemic Relief: Labor and Family Policies in Denmark, Germany, and the United States During COVID-19. American Behavioral Scientist <https://journals.sagepub.com/doi/10.1177/00027642211003140> (2021, July, 29). [in English].

4. Bariola, N., Collins, C. (2021). The Gendered Politics of Pandemic Relief: Labor and Family Policies in Denmark, Germany, and the United States During COVID-19. American Behavioral Scientist 〈https://journals.sagepub.com/doi/10.1177/00027642211003140> (2021, May, 21). [in English].

5. Behrendt, C., Nguyen, Q. A., Rani, U. (2019). Social protection systems and the future of work: Ensuring social security for digital platform workers. International Social Security Review, 72 (3), 17-41. [in English].

6. Blum, S., Kuhlmann, J., Schubert, K. (2020). The Routledge handbook of European welfare systems. Oxon: Routledge. [in English].

7. Blumenthal, D., Fowler, E. J., Abrams, M., Collins, S. R. (2020). Covid-19: Implications for the Health Care System. New England Journal of Medicine, 383(15), 1483-1488. [in English].

8. Blumenthal, D., Fowler, E. J., Abrams, M., Collins, S. R. (2020). Covid-19: Implications for the Health Care System. New England Journal of Medicine, 383 (15), 1483-1488. [in English].

9. Cook, R., Grimshaw, D. (2020). A gendered lens on COVID-19 employment and social policies in Europe. European Societies, 23 (1), 215-227. [in English].

10. COVID-19 hospitalization and death by race/ethnicity (2020). Centers for Disease Control and Prevention $<$ https://www.cdc.gov/coronavirus/2019-ncov/covid-data/investigations-discovery/ hospitalization-deathby-race-ethnicity.html> (2021, June, 11). [in English].

11. COVID-19 i Danmark. Epidemiologisk trend og fokus: Herkomst (etncitet) (2020). Statens Serun Institut <https://files.ssi.dk/COVID19-epi-trendogfokus-07052020-4eu7> (2021, June, 11). [in English].

\footnotetext{
${ }^{1}$ Craig, L., Churchill, B. (2020). Dual-earner parent couples' work and care during COVID-19. Gender, Work \& Organization, 28 (1), 66-79; Hipp, L., Bünning, M. (2020). Parenthood as a driver of increased gender inequality during COVID-19? Exploratory evidence from Germany. European Societies, 23 (1), 658-673; Qian, Y., Fuller, S. (2020). COVID-19 and the gender employment gap among parents of young children. Canadian Public Policy, 46 (2), 89-101.
} 
12. Craig, L., Churchill, B. (2020). Dual-earner parent couples' work and care during COVID-19. Gender, Work \& Organization, 28 (1), 66-79. [in English].

13. Dubay, L., Aarons, J., Brown, K. S., Kenney, G. M. (2020). How risk of exposure to the Coronavirus at work varies by race and ethnicity. Washington: Urban Institute. [in English].

14. Norwegian Government (2020). Economic measures in Norway in response to Covid-19 $<$ https://www.regjeringen.no/en/topics/the-economy/economic-policy/economic-measures-in-norway-in-responseto-covid-19/id2703484/> (2021, June, 14). [in English].

15. Esping-Andersen, G. (1990). The Three Worlds of Welfare Capitalism. Princeton: Princeton University Press. [in English].

16. Esping-Andersen, G. (1999). Social Foundations of Postindustrial Economies. Oxford: Oxford University Press. [in English].

17. Gonzalez, O., Davis, L. M. (2021). What's happening to federal unemployment benefits after summer? Here's what we know. CNET <https://www.cnet.com/personal-finance/your-money/whats-happening-to-federalunemployment-benefits-after-summer-heres-what-we-know/> (2021, June, 17). [in English].

18. Greve, B. (2016). Denmark: Still a Nordic welfare state after the changes of recent years? In K. Schubert, P. Villota, J. Kuhlman (Eds.), Challenges to European welfare systems Cham: Springer International Publishing, 159-176. [in English].

19. Greve, B. (2019). Welfare, populism and welfare chauvinism. Bristol: Policy Press. [in English].

20. Greve, B., Blomquist, P., Hvinden, B., van Gerven, M. (2021). Nordic welfare states - still standing or changed by the COVID-19 crisis? Social Policy \& Administration, 55 (2), 295-311. [in English].

21. Helliwell, J., Layard, R., Sachs, J., De Neve, J. E. (2020). World Happiness Report 2020. New York: Sustainable Development Solutions Network. [in English].

22. Hill, S. (2015). Raw deal. How the "Uber Economy" and runaway capitalism are schrewing American workers. New York: St. Martins Press. [in English].

23. Hipp, L., Bünning, M. (2020). Parenthood as a driver of increased gender inequality during COVID-19? Exploratory evidence from Germany. European Societies, 23 (1), 658-673. [in English].

24. Hirvonen, S. (2020). Helsingissä somalinkielisten koronavirustartunnat ovat selkeästi lisääntyneet, kaupunki ja HUS huolestuneita tilanteesta - Apulaispormestari vetoaa ohjeiden noudattamiseen alkavan ramadanin aikana [Somali-speaking coronavirus infections have clearly increased in Helsinki, the city and HUS are concerned about the situation - Deputy Mayor calls for following instructions during Ramadan]. Yle <https://yle.fi/uutiset/3-11305135> (2021, 11 June). [in Finnish].

25. Kangas, O., Kvist, J. (2019). Nordic Welfare States. In: Greve, B. (ed.) (2019). Routledge Handbook of the Welfare State. Oxon: Routledge, 124-136. [in English].

26. Keskimäki, I., Atkins, S., Merisalo, M., Rautianen, P., Tynkkynen, L.-K. (2020). Policy responses for Finland. Measures in other sectors. COVID-19 Health System Response Monitor <https://www.covid19healthsystem.org/ countries/finland/livinghit.aspx?Section=6.1\%20Measures\%20in\%20other\%20s > (2021, July, 24). [in English].

27. Khoma, N. M. (2010). Kryza skandynavskoi modeli sotsialnoi derzhavy: prychyna, naslidky, shliakhy vykhodu [The crisis of the Scandinavian model of the welfare state: cause, consequences, ways out]. Derzhava $i$ pravo [State and law], 50, 700-708. [in Ukrainian].

28. Khoma, N. M. (2010). Osoblyvosti funktsionuvannia skandynavskoi modeli sotsialnoi derzhavy: porivnialnyi aspekt [Features of the functioning of the Scandinavian model of the welfare state: a comparative aspect]. Porivnialno-pravovi doslidzhennia [Journal Comparative Legal Studies], 2, 157-165. [in Ukrainian].

29. Khoma, N. M. (2012). Modeli sotsialnoi derzhavy: svitovyi ta ukrainskyi dosvid [Models of the welfare state: global and Ukrainian experience]. Kyiv: Yurydychna dumka. [in Ukrainian].

30. Khoma, N., Vdovychyn, I. (2020). Deconstruction of the Welfare State: The Impact of Globalization and Technological Factors. Revija za socijalnu politiku, 27 (3), 269-285. [in English].

31. Leitner, S., Lessenich, S. (2003). Assessing welfare state change: The German social insurance state between reciprocity and solidarity. Journal of Public Policy, 23 (3), 325-347. [in English].

32. Martela, F., Greve, B., Rothstein, B., Saari, J. (2020). The Nordic exceptionalism: What explains why the Nordic countries are constantly among the happiest in the world. In: Neve, J. E. D., Helliwell, J., Layard, R., Sachs, J. D. (eds.) (2020). World Happiness Report, 2020. New York: Sustainable Development Solutions Network. [in English].

33. Norwegian Government (2020). Meld. St. 2 (2019-2020) Melding til Stortinget - Revidert nasjonalbudsjett $<$ https://www.regjeringen.no/contentassets/f7f> (2021, 20 June). [in Norwegian].

34. Meuleman, B., van Oorschot, W., Gugushvili, D. et al. (2018). The Past, Present and Future of European Welfare Attitudes: Topline Results from Round 8 of the European Social Survey. ESS Topline Series. [in English].

35. Miller, C. C. (2020). Private tutors, pop-up schools or nothing at all: How employers are helping parents. The New York Times, September, 17. [in English].

36. Miller, C. C., Tankersley, J. (2020). Paid leave law tries to help millions in crisis: Many haven't heard of it. The New York Times, May, 8. [in English].

37. Bipartisan Policy Center (2020). New BPC/morning consult survey of small business owners: Family and child responsibilities are top challenges during COVID-19<https://bipartisanpolicy.org/blog/new-bpc-morning-consult- 
survey-of-small-business-owners-family-and-child-responsibilities-are-top-challenge-during-covid-19/> (2021, May, 18). [in English].

38. Novoa, C. (2020). How child care disruptions hurt parents of color most. Center for American Progress $<$ https://www.americanprogress.org/issues/early-childhood/news/2020/06/29/486977/child-care-disruptions-hurtparents-color/> (2021, July, 02). [in English].

39. Powell, C. (2020). The color and gender of COVID: Essential workers, not disposable people. Think Global Health <https://www.thinkglobalhealth.org/article/color-and-gender-covid-essential-workers-not-disposable-people> (2021, July, 23). [in English].

40. Qian, Y., Fuller, S. (2020). COVID-19 and the gender employment gap among parents of young children. Canadian Public Policy, 46 (2), 89-101. [in English].

41. Radcliff, B. (2013). The political economy of human happiness: How voters' choices determine the quality of life. Cambridge: Cambridge University Press. [in English].

42. Rao, A. H. (2020). Crunch time: How married couples confront unemployment. Oakland: University of California Press. [in English].

43. Roosma, F., Gelissen, J., Van Oorschot, W. (2013). The Multidimensionality of Welfare State Attitudes: A European Cross-national Study. Social Indicators Research, 113 (1), 235-255. [in English].

44. Schanzenbach, D. W., Pitts, A. (2020). How much has food insecurity risen? Evidence from the Census Household Pulse Survey. Institute for Policy Research Rapid Research Report $\langle$ https://www.ipr.northwestern.edu/documents/reports/ipr-rapid-researchreports-pulse-hh-data-10-june-2020.pdf > (2021, August, 01). [in English].

45. Scruggs, L. A., Allan, J. P. (2008). Social Stratification and Welfare Regimes for the Twenty-first Century: Revisiting the Three Worlds of Welfare Capitalism. World Politics, 60 (4), 642-664. [in English].

46. Thompson, D. (2020). Do more - fast. Don't wait. The Atlantic, March 24. [in English].

47. Public Health Agency (2020). Veckorapport om Covid-19 [Weekly report on Covid-19] <https://www.folkhalsomyndigheten.se/globalassets/statistik-uppfoljning/smittsamma-sjukdomar/veckorapportercovid-19/2020/covid-19-veckorapport-vecka-32-final-v2.pdf> (2021, 21 July). [in Swedish].

48. Wiking, M. (2016). Why Danes happily pay high rates of taxes. US News and World Report <https://www.usnews.com/news/best-countries/articles/2016-01-20/why-danes-happily-pay-high-rates-of-taxes> (2021, July, 29). [in English]. 